\title{
EFFECTS OF HYPODYNAMY ON THE REPRODUCTIVE FUNCTIONS OF JAPANESE QUAIL
}

\author{
V. SABO, K. BOĎA, V. CHRAPPA. P. SKKROBÁNEK ${ }^{+}$, P. VÝBOH
}

Institute of Animal Biochemistry and Genetics, SAS, 90028 Ivanka pri Dunaji, Slovak Republic

${ }^{+}$Research Institute of Animal Production, Nitra, Poultry Breeding Station, Slovak Republic

Received April 18, 1995

Accepted June 6, 1996

\begin{abstract}
Sabo, V., K. Bod'a, V. Chrappa, P. Śkrobánek, P. Výboh: Effects of Hypodynamy on the Reproductive Functions of Japanese Quail. Acta vet. Brno 1996, 65: 65-71.

Japanese quail kept individually in cages were inseminated under conditions of 22-day hypodynamy. Fertility and hatchability of their eggs were assessed.

The efficiency of the insemination depended on the number of inseminations. Compared with the results obtained upon natural breeding, it was $58.2 \%$ lower in quail inseminated twice and $35.9 \%$ lower in birds inseminated theree times in individual cages; under the conditions of hypodynamy it was $62.8 \%$ lower after two inseminations and $41.7 \%$ lower after theree inseminations. There were no substantial differences in egg production between the groups.

In male quail subjected to 22-day hypodynamy semen volume, sperm concentration and blood plasma testosterone level were reduced.

It is recommended that under space flight conditions quail should be inseminated every two or three days and the male-female ratio should be 1:1. Selection should be made of male quail having high semen volume and high sperm concentration on the basis of their blood plasma testosterone level under the conditions of hypodynamy.
\end{abstract}

Japanese quail, fertility, insemination, plasma testosteron

The results obtained so far both in model experiments on Earth and under space flight conditions have provided a basis for achieving a long-term objective - to conclude the reproductive cycle of Japanese quail under microgravity conditions and to produce Japanese quail cosmic population ( B o d a 1979).

Evidence has been obtained to indicate that in microgravity the embryonic development and hatching of Japanese quail from eggs that were fertilized and developed in the oviduct and uterus under gravity conditions is possible ( Me le s h k o et al. 1991; B o d a et al. 1991). However, the question remains as to the effect of gravity on fertilization and embryonic development in the oviduct from fertilization to egg-laying and particularly on the development of dorso-ventral and cranio-caudal polarity.

The blastoderm of a newly-laid egg is a bilateral symmetric system (V on B a er 1928). Some writers (Clevert et al. 1955; Vintemberg et al. 1960; Clevert 1963) have concluded that the bilateral symmetry is shifted by rotation of the egg in the uterus and that the inclination changes the position of the axis. These writers did not regard gravity as playing a major role in this process.

According to other writers (Kochava et al. 1971; Eyal-Giladi et al. 1980; Fabi an et al. 1981) gravity is a prerequisite for development of the cranio-caudal polarity. The definitive answer as to the possibility of fertilization in weightlessness and the influence of gravity on the development of symmetry can be given only by experiments conducted under the conditions of microgravity.

We attempted to contribute to the resolution of this problem on an experimental hypodynamy model used successfully in our previous experiments on Japanese quail ( Ju rán $i$ et al. 1983; J u rá $\mathrm{ni}$ et al. 1988) in studies on the processes of adaptation of the productive and reproductive functions of experimental birds. 
The present study was designed to find whether or not the development of Japanese quail embryos was affected by long-term hypodynamy. The results of the experiment might provide indirect evidence for the effect of hypodynamy on the fertilization and development in the oviduct of Japanese quail. Another objective was to investigate the efects of hypodynamy on the efficiency of insemination and on spermiogenesis. The results are to be used as a basis for developing the methods of fertilization by insemination under microgravity conditions.

\section{Materials and Methods}

Japanese quail aged 60 days were divided into five groups:

Group 1 representing natural breeding included 10 male and 10 female birds housed in cages (one male and one female to a cage) and served as controls.

Group 2 included 10 female birds kept individually in cages and each inseminated on days 10 and 18 , the interval between inseminations being 7 days.

Group 3 included 10 female birds kept individually in cages and each inseminated on days 10,14 and 18, the interval between inseminations being 3 days.

Group 4 included 10 female birds restrained in ,jackets“ (hypodynamy) and inseminated on days 10 and 18, the interval between inseminations being 7 days.

Group 5 included 10 female birds restrained in ,jackets“ (hypodynamy) and each inseminated on days 10, 14 and 18 , the interval between inseminations being 3 days.

During the experiment the eggs were collected and put into incubators at the following intervals:

(1) on day 10 of the experiment - start of insemination

(2) on day 14 of the experiment

(3) on day 18 of the experiment

(4) on day 22 of the experiment - termination of hypodynamy

(5) on day 25 of the experiment - end of the experiment.

The experimental groups were in hypodynamy for 22 days. The experimental design is shown in Table 1 . The percentages of fertilized eggs, hatchability and egg production were recorded.

In 8 male Japanese quail semen volume and sperm concentration were assessed. Five semen collections were made during 10 days before hypodynamy and 4 semen collections were carried out during 15-day hypodynamy.

Table 1

Experimental design

\begin{tabular}{|ccccc|}
\hline Group & No. birds & Breeding & Restraint & $\begin{array}{c}\text { Interval } \\
\text { between } \\
\text { inseminations } \\
\text { (in days) }\end{array}$ \\
\hline No. & $10^{*}+10^{\bullet}$ & Natural & - & - \\
\hline 2 & $1 \bullet^{\bullet}$ & Insemination & - & 7 \\
\hline 3 & $1 \bullet^{-}$ & Insemination & - & 4 \\
\hline 4 & $10^{-}$ & Insemination & Hypodynamy & 7 \\
\hline 5 & $10^{-}$ & Insemination & Hypodynamy & 4 \\
\hline
\end{tabular}

The investigation also covered blood plasma testosterone level before and during the 15-day hypodynamy.

\section{Results and Discussion}

Table 2 shows the fertility of eggs (in \%) upon insemination of unrestrained birds (Groups 2 and 3 ) and of birds in hypodynamy (Groups 4 and 5).

The fertility of eggs in quail kept kept under natural breeding conditions (Group 1) was $84.4 \%$. In twice inseminated quail it was $31.6 \%$ in unrestrained birds (Group 2) and only $21.6 \%$ in those in hypodynamy (Group 4 ).

In the groups inseminated three times the fertility of eggs was higher, amounting to $48.5 \%$ 
in unrestrained birds (Group 3) and $42.7 \%$ in those in hypodynamy (Group 5). The differences between the groups were significant as can be seen in Fig. 1. The results of hatchability are shown in Table 3 and Fig. 2.

Table 2

Percentages of fertilized eggs of Japanese quail during the experiment

\begin{tabular}{|c|c|c|c|c|c|c|c|}
\hline Group No. & Treatment & \multicolumn{6}{|c|}{ Days of experiment } \\
\hline & & 10 & 14 & 18 & 22 & 25 & $14-25$ \\
& & & & & & & \\
2 & $*+\bullet$ & 46,1 & 85,2 & 82,7 & 87,5 & 82,4 & 84,4 \\
3 & $\cdot 2 \times \mathrm{i}$ & 11,7 & 34,2 & 31,0 & 28,2 & 33,3 & 31,6 \\
4 & $\cdot 3 \times \mathrm{i}$ & 11,7 & 38,2 & 51,8 & 74,2 & 29,6 & 48,5 \\
5 & $\mathrm{H} \cdot 2 \times \mathrm{i}$ & 0,0 & 16,6 & 15,3 & 27,2 & 27,2 & 21,6 \\
& $\mathrm{H} \cdot 3 \times \mathrm{i}$ & 0,0 & 33,3 & 45,4 & 58,8 & 33,3 & 42,7 \\
\hline
\end{tabular}

$\mathrm{H}=$ hypodynamy

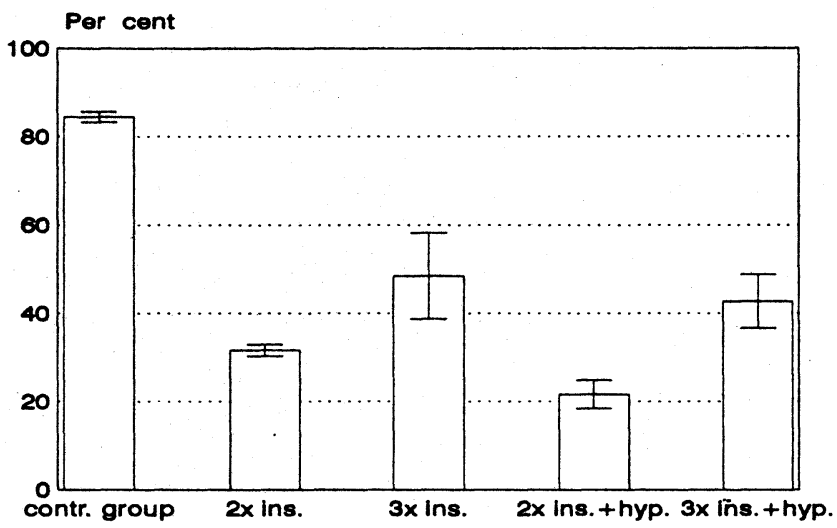

Fig. 1. Fertility of control and experimental Japanese quail

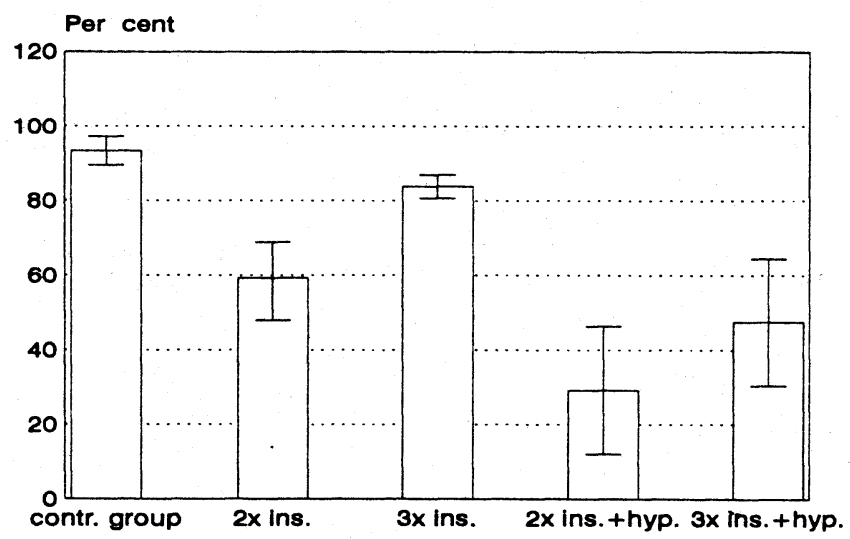

Fig. 2. Egg hatchability of control and experimental Japanese quail 
To elucidate the effect of insemination on egg production we also recorded the per cent egg production in the five groups for the whole experimental period (Table 4). As can be seen only Group 5 (birds inseminated three times in hypodynamy) was influenced by insemination.

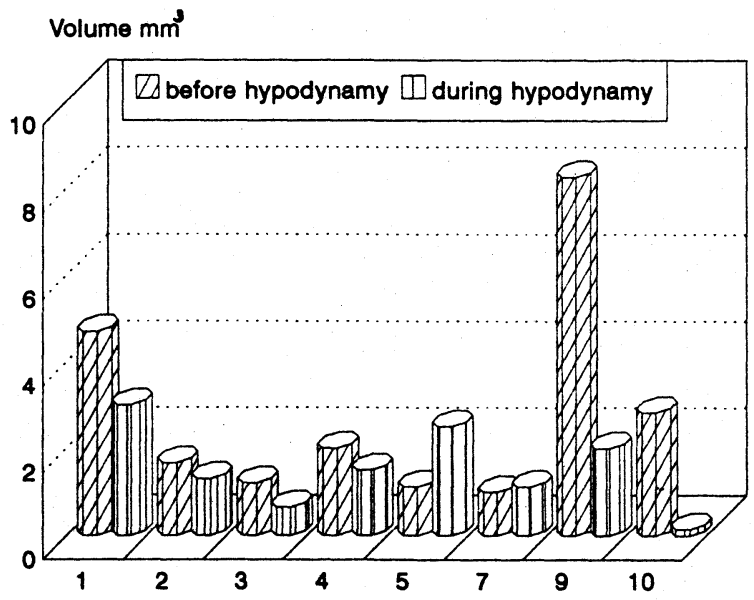

Fig. 3. Semen volume of Japanese quail males mil. per $\mathrm{mm}^{3}$

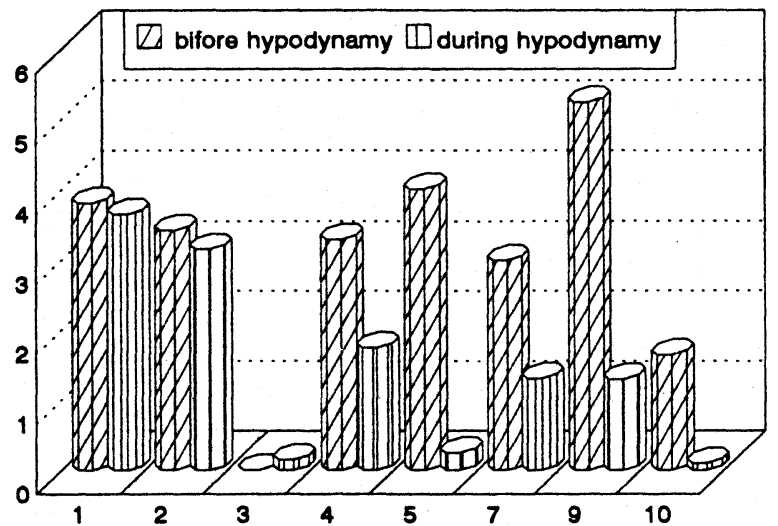

Fig. 4. Sperm concentration of Japanese quail males

The mean semen volume and sperm concentration of male quail before and during hypodynamy are shown in Fig. 3 and 4. As can be seen the semen volume collected in hypodynamy was lower in 6 out of the 8 male birds. Sperm concentration was lower in all the birds in hypodynamy.

Blood plasma concentration level showed a significant decrease $(1.11 \pm 0.84 \mathrm{ml})$, compared with the basal testosterone level recorded before hypodynamy $(5.22 \pm 0.89 \mathrm{ml})$. The decreased testosterone concentration correlated with the changes in semen volume and sperm concentration induced by hypodynamy.

The efficiency of fertilization was highest (84.4\%) in birds kept under natural breeding conditions. The fertility of eggs laid by birds inseminated twice during a 9-day period was $31.6 \%$ and in those inseminated three times during the same period, $48.5 \%$. The percentages of fertilization were higher than those reported by Wil s on et al. (1961) and B a u m- 
gartne $r$ et al. (1975) who recorded $10 \%$ and $24,35 \%$, respectively. It can be seen that fertility after insemination is about $50 \%$ lower than under natural breeding conditions.

In our experiments the fertilization of eggs laid by Japanese quail kept under the 22-day hypodynamy conditions was reduced. However, when the insemination was repeated three times, the fertilization rate was improved, almost approaching that recorded for unrestrained birds.

Table 3

Per cent hatchability of Japanese quail eggs in the course of the experiment

\begin{tabular}{|l|l|r|r|r|r|r|r|}
\hline \multirow{2}{*}{ Group No. } & \multirow{2}{*}{ Treatment } & & \multicolumn{5}{|c|}{ Days of experiment } \\
\cline { 3 - 8 } & & 10 & 14 & 18 & 22 & 25 & $14-25$ \\
\hline 1 & $*+\cdot$ & 75,0 & 93,1 & 100,0 & 97,6 & 82,6 & 93,3 \\
\hline 2 & $\cdot 2 \times \mathrm{i}$ & 0,0 & 84,6 & 44,4 & 63,6 & 44,4 & 59,2 \\
\hline 3 & $\cdot 3 \times \mathrm{i}$ & 50,0 & 84,6 & 85,7 & 89,6 & 75,0 & 83,7 \\
\hline 4 & $\mathrm{H} \cdot 2 \times \mathrm{i}$ & 0,0 & 0,0 & 0,0 & 50,0 & 66,6 & 29,1 \\
\hline 5 & $\mathrm{H} \cdot 3 \times \mathrm{i}$ & 0,0 & 0,0 & 60,0 & 80,0 & 50,0 & 47,5 \\
\hline
\end{tabular}

$\mathrm{H}=$ hypodynamy

Table 4

Per cent egg production by Japanese quail recorded for the whole experimental period

\begin{tabular}{|l|l|l|}
\hline Group No. & Treatment & $\begin{array}{l}\text { Egg production } \\
\text { (in \%) }\end{array}$ \\
\hline 1 & $\cdot+\cdot$ & 88,80 \\
\hline 2 & $\cdot 2 \times \mathrm{i}$ & 86,80 \\
\hline 3 & $\cdot 3 \times \mathrm{i}$ & 86,80 \\
\hline 4 & $\mathrm{H} \cdot 2 \times \mathrm{i}$ & 34,80 \\
\hline 5 & $\mathrm{H} \cdot 3 \times \mathrm{i}$ & 30,16 \\
\hline
\end{tabular}

$\mathrm{H}=$ hypodynamy

Likewise spermiogenesis (semen volume and sperm concentration) and blood plasma testosterone level of male birds kept under 15-day hypodynamy were reduced. Fig. 3 and 4 show semen volume and sperm concentration values od each bird. Of particular interest are considerable differences in these values from bird to bird. In some cases, except birds 5 and 7 as regards semen volume and bird 3 as regards sperm concentration, the values recorded under the conditions of hypodynamy were lower. Correlation was found between blood plasma testosterone level and both semen volume and sperm concentration. These results indicate the necessity of individual selection of experimental birds on the basis pf their blood plasma testosterone level.

The results reported here are of value to space flight experiments designed to conclude the reproductive cycle of Jpanese quail in microgravity. Moreover, such experiments may answer the question as to the effect of gravity on formation of the embryonic bilateral symmetry.

Use of the results obtained in our experiments conducted under hypodynamy conditions may help the reduce the risk of fertilization failure. 
An unequivocal conclusion from our results is that under microgravity conditions insemination must be carried out every two or three days and that to ensure adequate sperm production the male-female ratio should be $1: 1$ and not 1:3 as previously thought.

\section{Vplyv hypodynamie na reprodukčné funkcie japonských prepelíc}

Japonské prepelice chované individuálne $\mathrm{v}$ klietkach boli inseminované $\mathrm{v}$ podmienkach hypodynamie trvajúcej 22 dní. Hodnotená bola fertilita a liahnivost ich vajec.

Efektívnost' inseminácie závisela na počte inseminácií. Pri porovnaní s výsledkami získanými pri prirodzenom párení, bola o 58,2 \% nižšia u prepelíc inseminovaných $2 x$ a o 39,5 $\%$ nižšia u $3 \mathrm{x}$ inseminovaných samíc chovaných jednotlivo $\mathrm{v}$ klietkach. $\mathrm{V}$ podmienkach hypodynamie to bolo $62,8 \%$ nižšie po 2 insemináciách a o $41,7 \%$ nižšie po 3 insemináciách. $\mathrm{V}$ produkcii vajec neboli medzi skupinami podstatné rozdiely.

U samcov podrobených 22 dní trvajúcej hypodynamii boli znížené objemy ejakulátu, koncentrácia spermií a koncentrácia testosteronu v krvnej plazme.

Doporučuje sa, aby v podmienkach orbitálnych letov boli prepelice inseminované každé 2 alebo 3 dni a aby pomer samcov a samíc bol 1:1. Selekcia samcov by mala byt zameraná na jedince s velkým objemom ejakulátu a vysokou koncentráciou spermií na základe sledovanej koncentrácie testosteronu $\mathrm{v}$ krvnej plazme $\mathrm{v}$ podmienkach hypodynamie.

\section{Влияние гиподинамии на функции воспроизводства японских перепелок}

Проводили оплодотворение японских перепелок в условиях индивидуального содержания в клетках при 22 суточной гиподинамии. Наблюдали за фертильностью и вылупливаемостью яиц.

Эффективность оплодотворения находилась в зависимости от числа оплодотворений. По сравнению с естественным оплодотворением у расположенных в индивидуальных клетках перепелок при дважды повторяемом оплодотворении она была меньше на 52,8 \%, и при трижды повторяемом оплодотворении - на 35,9 \%. В условиях гиподинамии успех дважды повторяемого оплодотворения был меньше на $62,8 \%$, после трижды повторяемого оплодотворения - на $41,7 \%$.

Оплодотворение не оказало существенного влияния на яйцекладку исследуемых перепелок.

После 22 суточной гиподинамии у петушков наблюдали уменьшение объема эякулята, концентрации спермий и понижение тестостерона в плазме.

При попытках летать рекомендуем оплодотворять на вторые - третьи сутки с обеспечением соотношения полов 1:1. Целесообразно проведение индивидуального отбора петушков свысоким объемом эякулята и высокой концентрацией спермий в условиях гиподинамии на основе уровня тестостерона в плазме.

\section{References}

BAUMGARTNER, J., SPRONC, A., CSUKA, J. 1975: Živ. výr. 20: 463.

BOḊA, K. 1975: Tech. práca, 6: 23-27.

BOḊA, K., MELESHKO, G. I., SABO, V., SHEPELEV, Ye. Ya., GURYEVA, T. S., JURÁNI, M., KOŠTÁL, L. 1991: The Physiologist Suppl. 34: S59-S61.

CLEVERT, J., VINTEMBERGER, P. 1955: CR Soc. Biol. Paris 149: 413-415.

CLEVERT, J. 1963: Advan. in Morf. 2: 27-60. 
EYAL-GILADI, H., FABIAN, B. C. 1980: Develop. Biol. 77: 228-232.

FABIAN, B. C., EYAL-GILADI, H. 1981: J. Embryolog. Exp. Morph. 64: 11-22.

JURANI, M., VYYBOH, P., LAMOŚOVÁ, D., BAROŠKOVÁ, Ž., SOMOGYOVÁ, E., BOḊ, K., GAŽO, M. 1983: The Physiologist Suppl. 26: 145-148.

JURÁNI, M., BOḊA, K., KOSTÁL, L., SOMOGYOVÁ, E., LAMOŠOVÁ, D., VÝBOH, P., AMBRUŠ, B., BAUMGARTNER, J. 1988: The Physiologist Suppl. 31: 140-142.

KOCHAVA, S., EYAL-GILADI, H. 1971: Science 171: 1027-1029.

MELESHKO, G. I., SHEPELEV, Ye. Ya., GURYEVA, T. S., BODA, K., SABO, V. 1991: Spac. Biol. Aerosp. Medic. 25: 33-39.

VITEMBERGER, P., CLEVERT, J. 1960: C. R. Soc. Biol. 154: 1072-1076.

VON BAER, K. E. 1828: Bonnträger, Konigsberg 315.

WILSON, W. O., ABBOTT, U. K., ABPLANALP, H. 1961: Poultry Sci. 40: 651. 